\title{
Introdução - $\bigcirc$ testemunho das coisas úteis e duráveis
}

Introduction - Testimony of useful and lasting things

JOSÉ NEWTON COELHO MENESES'

Universidade Federal de Minas Gerais / Belo Horizonte, MG, Brasil

\section{MARIA APARECIDA DE MENEZES BORREGO²}

Universidade de São Paulo / São Paulo, SP, Brasil

Tomados como objetos de discussão e de busca de compreensão, para além de suas materialidades, os artefatos de uso humano - sejam instrumentais, simbólicos, práticos, utilitários ou como queiram pensá-los - remetem a questionamentos a respeito de como eles nos servem de fontes históricas e de como documentam contextos sociais, histórias de vida, vivências humanas, experiências cotidianas.

Neste dossiê, conjunto rico e diverso de textos interpretativos, as coisas dos homens apresentam-se como "cotidiano material", "cultura material", "elementos materiais", "peças de uso funcional", "bens do aparato social", "objetos materiais", artefatos "técnicos e materiais", atendendo à busca compreensiva dos autores dos artigos no intuito de evidenciar a história das coisas e dos homens que as usam, ou a história dos homens usando coisas.

Usos e coisas; costumes e utilizações! A ideia do que é útil ao homem move o pensar sobre a vida e sobre as vivências. Conduz a reflexões acerca de
1. Docente do Departamento de História - Fafich-UFMG. E-mail: <jnmeneses@uol.com.br>.

2. Historiadora. Docente do Departamento de Acervo e Curadoria do Museu Paulista e do Programa de Pós-Graduação em História Social da Faculdade de Filosofia, Letras e Ciências Humanas da Universidade de São Paulo. E-mail: <maborrego@usp.br>. 
3. Meneses (1998, p. 90).

4. Bluteau (1721, v. 8, p. 600).

5. Cf. Miller (2013).

6. Assim nomeada na tradição historiográfica e teorizada, dentre outros textos e autores, por Bucaille e Pesez (1989). construções culturais, sociabilidades, formas de pensar, de enriquecer, técnicas, estratégias de sobrevivência e, ainda, representações sociais de nosso mundo em tempos passados; e o faz pelos artefatos que a vida constrói.

Ulpiano Bezerra de Meneses nos alerta sobre o valor das coisas das pessoas como documentos de sua história, mas distingue a integridade física dos objetos - como a verdade acerca deles - dos discursos que se constroem a partir dessa physis. $\bigcirc$ autor afirma que "a simples durabilidade do artefato, que em princípio costuma ultrapassar a vida de seus produtores e usuários originais, iá o torna apto a expressar o passado de forma profunda e sensorialmente convincente". ${ }^{3}$ Durabilidade e utilidade dão aos objetos o caráter de testemunho e são, portanto, fatores que levam o historiador a ler o artefato que dura no tempo.

"Útil", desde os dicionários do século XVIII, é palavra indicadora de uma coisa que tem proveito ou préstimo e serve para algo. "Utilizar" ou "usar" é aproveitar as coisas. ${ }^{4}$ A vida exige objetos úteis, os quais são criados em proveito das pessoas e por elas, para que sirvam à sua sobrevivência material e à sua inteligência, ao seu espírito, à sua sociabilidade. Ao usar proveitosamente os artefatos que inventa, o ser humano, com os gestos do uso, inscreve nos próprios objetos as marcas do tempo. Do seu tempo. O objeto e seu uso são fatos históricos e tornam-se documentos da História quando o historiador os submete à leitura crítica.

Os artefatos são parte da cultura e integram-se à vivência humana de forma inseparável. São elementos materiais da cultura e não apenas a representação material dela. ${ }^{5}$ Eles incorporam os gestos no uso e se reinscrevem em um cotidiano de que são parte, mas não só: o objeto integra-se ao corpo humano, associa-se à razão, participa da sociabilidade, do desejo dos homens e é símbolo de construções diversas da imaginação. São intrínsecos aos atos vividos.

A cultura material, reforçada pela tradição que nomeia assim a busca interpretativa dos bens materiais das sociedades, objetiva, em verdade, compreender os elementos materiais da cultura ou a dimensão palpável de uma realidade vivida. E é a partir dessas plataformas de observação que os historiadores e outros cientistas sociais têm buscado compreender as transformações sociais pela leitura das coisas da vida. Não há uma cultura material e outra imaterial, embora essa distinção tenha propiciado importantes mudanças no reconhecimento de patrimônios culturais. Existem culturas, e elas possuem elementos materiais e simbólicos integrados, articulados ao fazer e ao saber da vida em sociedade.

Os historiadores são reconhecidos em seu ofício porque dispõem de fontes; sabem lê-las à luz de perspectivas analíticas e de instrumentos metodológicos específicos; admitem suas historicidades e se valem delas como suporte para 
mediar o acesso a um mundo do qual elas são mais que vestígio. Os elementos materiais da cultura são documentos primordiais para o conhecimento histórico, e saber mobilizá-los favorece compreensões complexas de um passado que não passa por completo, um passado igualmente durável.

Como mostram os textos deste dossiê, segunda edição do publicado no ano de 2017, intitulado Cultura material no universo dos Impérios europeus modernos, os objetos se apresentam como coleções museológicas a denotarem o patrimônio das populações nativas das terras baixas da América do Sul que os produziram, testemunhando suas especificidades culturais, na abordagem de Glória Kok. Eles também são mostra das artes, dos saberes e das riquezas de homens do sertão colonial do Tejuco, em Minas Gerais, estudados por Régis Quintão, ou de Cantagalo, no Rio de Janeiro, pesquisados por Sheila de Castro Faria, nas últimas décadas do século XVIII e primeiras do XIX. Compõem, ainda, um repertório de técnicas, matérias-primas e circunstâncias sociais na construção de produtos visuais nos manuscritos do mesmo período, escrutinado por Marcia Almada. Em um tempo mais alargado, entre os séculos XVI e XVIII, Luís Frederico Dias Antunes analisa a vida social dos tecidos da Índia, entrelaçando algodões asiáticos e lanifícios europeus que frequentam o mundo português como mercadorias, presentes, objetos suntuários e comuns, aquecendo casas e corpos.

Os textos falam assim dos homens, suas coisas e suas vidas no mundo colonial português, vistos a partir de perspectivas técnicas, museais, arquivísticas e historiográficas, de tempos longos, sob a leitura de autores do século XXI. Largo mundo de coisas móveis e duráveis. 


\section{REFERÊNCIAS}

FONTES IMPRESSAS

BLUTEAU, Raphael. Vocabulario portuguez e latino. Coimbra: Collegio das Artes da Companhia de Jesus, 1712-1721. $10 \mathrm{v}$.

LIVROS, ARTIGOS E TESES

BUCAILLE, Richard; PESEZ Jean-Marie. Cultura material. In: Enciclopédia Einaudi. Lisboa: IN-CM, vol.16, 1989, p. 11-47.

MENESES, Ulpiano T. Bezerra de. Memória e cultura material: documentos pessoais no espaço público. Estudos Históricos, Rio de Janeiro, v. 11, n. 21, 1998, p. 89-103.

MILLER, Daniel. Trecos, troços e coisas. Estudos antropológicos sobre cultura material. Rio de Janeiro: Zahar, 2013.

All the contents of this journal, except where otherwise noted, is licensed under a Creative Commons Attribution License

\section{(cc) BY}

